\title{
COMPARATIVE ANALYSIS OF WALNUTS AND PEANUTS OILS
}

\author{
SABINA NIȚU ${ }^{\mathrm{a}}$, MIRABELA PĂDURE ${ }^{\mathrm{a}}$, ANDRA TĂMAȘ ${ }^{\mathrm{a}, *}$, \\ LUCIAN MIRCEA RUSNAC ${ }^{a}$
}

\begin{abstract}
In this paper, a comparative study of the physico-chemical properties and composition of walnuts and peanuts oils obtained by cold pressing or Soxhlet extraction in hexane was performed. The physical properties (color, density, refractive index, acidity, saponification, iodine and peroxide values, rheological behavior), the distribution of the major fatty acids in oils (through gas-chromatographic analysis) and the metal content were determined.
\end{abstract}

Keywords: cold pressing, extraction, oil, peanuts, viscosity, walnuts

\section{INTRODUCTION}

Peanuts or hazelnuts are the fruits of a leguminous plant (Arachis Hipogaea) which are often included in the walnut category, due to their composition, properties and similar benefits.

Although walnuts are the fruits of the walnut tree (Juglans regia L.), they do not have a characteristic sweet taste of fruits and are noted for their high content of fats and nutrients (vitamin $\mathrm{E}$ and $\mathrm{B1}, \mathrm{Mg}, \mathrm{Ca}, \mathrm{Cu}, \mathrm{Mn}, \mathrm{P}$, fiber), which gives them an appreciated nutritional value and multiple benefits for health. Recent studies have shown that walnuts, due to their high content of polyphenols, have an antioxidant capacity superior to fish oil [1]. The main benefits of walnuts consumption on health are: lowering of cholesterol and serum triglycerides [2], reducing blood pressure and the risk of heart attack $[3,4]$, hypoglycemic action for type 2 diabetes, anti-inflammatory action [5], antimicrobial activity [6].

Peanut oil, is quite rich in vitamin $\mathrm{E}$, which is an essential vitamin for human beings. It is particularly important for the maintenance and health of the skin, protecting it from the effects of free radicals that cause wrinkles, blemishes, and other signs of premature aging [7].

a Politehnica University of Timișoara, Faculty of Industrial Chemistry and Environmental Engineering, 6 Vasile Pârvan Bv., RO-300223, Timișoara, Romania

*Corresponding author: andra.tamas@upt.ro 
The pleasant taste, nutritional value and health benefits recommend the consumption of nuts as such or in the form of oil, especially that obtained by cold pressing.

The current policy of the European Union is directed towards stimulating nuts production by granting non-refundable financial aid for the establishment and development of nut tree cultures [8].

In this paper, a comparative study of the composition and physicochemical properties between walnuts and peanuts oil was carried out.

\section{RESULTS AND DISCUSSION}

For a number of three samples of walnuts/peanuts with known mass, the average moisture content is shown in Table 1.

Table 1. The moisture content of the raw nuts

\begin{tabular}{|c|c|}
\hline Type of nuts & Humidity (wt.\%) \\
\hline Walnuts & 2.0 \\
\hline Peanuts & 1.1 \\
\hline
\end{tabular}

The final separation yields compared to the amount of processed nuts are presented in Table 2, and the main properties of the oils are shown in Table 3.

Table 2. The final separation yields

\begin{tabular}{|c|c|c|c|}
\hline \multicolumn{3}{|c|}{ Oil obtained (wt.\% relative to nuts) } \\
\hline \multicolumn{3}{|c|}{ Walnuts } & \multicolumn{2}{c|}{ Peanuts } \\
\hline Cold pressing & Soxhlet extraction & Cold pressing & Soxhlet extraction \\
\hline 34 & 41 & 30 & 32 \\
\hline
\end{tabular}

Table 3. The main properties of the oils

\begin{tabular}{|c|c|c|c|c|}
\hline \multirow[t]{2}{*}{ Property } & \multicolumn{2}{|c|}{ Walnuts } & \multicolumn{2}{|c|}{ Peanuts } \\
\hline & $\begin{array}{c}\text { Cold } \\
\text { pressing }\end{array}$ & $\begin{array}{c}\text { Soxhlet } \\
\text { extraction }\end{array}$ & $\begin{array}{c}\text { Cold } \\
\text { pressing }\end{array}$ & $\begin{array}{c}\text { Soxhlet } \\
\text { extraction }\end{array}$ \\
\hline Appearance & $\begin{array}{l}\text { Pale } \\
\text { vellow }\end{array}$ & Yellowish & Yellowish & Yellowish \\
\hline Density, $\mathrm{g} \mathrm{cm}^{-3}$ & 0.927 & 0.926 & 0.918 & 0.908 \\
\hline $\begin{array}{l}\text { Refractive index ( } \mathrm{n}_{\mathrm{D}} \\
\left.20^{\circ} \mathrm{C}\right)\end{array}$ & 1.478 & 1.475 & 1.4714 & 1.4722 \\
\hline Acidity index $\left(\mathrm{mg} \mathrm{KOH} \mathrm{g}^{-1}\right)$ & 1.09 & 1.34 & 4 & 2.99 \\
\hline $\begin{array}{l}\text { Saponification value } \\
\left(\mathrm{mg} \mathrm{KOH} \mathrm{g}^{-1}\right)\end{array}$ & 188 & 193 & 182.53 & 161.12 \\
\hline lodine value, $\mathrm{g} \mathrm{I}_{2} / 100 \mathrm{~g}$ & 151.8 & 158.6 & 80.27 & 78.88 \\
\hline $\begin{array}{l}\text { Peroxide value, } \\
\left(\mathrm{mmol} \mathrm{O}_{2} \mathrm{~kg}^{-1}, \max \right)\end{array}$ & 8.2 & 8.9 & 0.05 & 3.61 \\
\hline
\end{tabular}


The density of peanuts oil is slightly lower than that of the walnuts oil, and the values obtained for the refractive index are almost identical for both types of oils, regardless of the obtaining method.

The iodine values are higher for walnuts oil than for peanuts oil, which proves a higher content of unsaturated triglycerides.

The peroxide values were higher for walnuts oil, the differences being justified by the higher content in unsaturated fatty acids demonstrated by the higher iodine values.

The results of the elemental analysis are presented in Table 4.

Table 4. The metal content of the oils

\begin{tabular}{|c|c|c|c|c|}
\hline \multirow{2}{*}{$\mathbf{m g ~ k g}^{-1}$ oil } & \multicolumn{2}{|c|}{ Walnuts oil } & \multicolumn{2}{c|}{ Peanuts oil } \\
\cline { 2 - 5 } & $\begin{array}{c}\text { Cold } \\
\text { pressing }\end{array}$ & $\begin{array}{c}\text { Soxhlet } \\
\text { extraction }\end{array}$ & $\begin{array}{c}\text { Cold } \\
\text { pressing }\end{array}$ & $\begin{array}{c}\text { Soxhlet } \\
\text { extraction }\end{array}$ \\
\hline $\mathrm{Pb}^{2+}$ & 0.081 & 0.059 & $<0.06$ & - \\
\hline $\mathrm{Cu}^{2+}$ & 0.268 & 0.256 & 0.184 & 0.276 \\
\hline $\mathrm{Zn}^{2+}$ & 55.93 & 42.35 & 29.9 & 33.5 \\
\hline $\mathrm{Fe}^{{ }^{+}}$ & 22.87 & 21.46 & 69.7 & 56.3 \\
\hline $\mathrm{Ca}^{2+}$ & 40.5 & 32.65 & 23.2 & 30.1 \\
\hline $\mathrm{Mg}^{2+}$ & 16.75 & 22.85 & 37.6 & 47.8 \\
\hline $\mathrm{Cr}^{3+}$ & 0.089 & 0.084 & 2.91 & 2.43 \\
\hline $\mathrm{Mn}^{2+}$ & 0.0029 & 0.0028 & - & - \\
\hline $\mathrm{Cd}^{2+}$ & 0.0021 & 0.0019 & 1.51 & 1.66 \\
\hline
\end{tabular}

Although the content of macroelements $\left(\mathrm{Ca}^{2+}, \mathrm{Mg}^{2+}, \mathrm{K}^{+}\right.$and $\left.\mathrm{Na}^{+}\right)$in nuts is important [9], these being linked to proteins, much smaller quantities pass into the oil. Potentially toxic elements $(\mathrm{As}, \mathrm{Cd}, \mathrm{Pb})$ indicate the degree of soil pollution in the area of origin. The higher $\mathrm{Fe}$ and $\mathrm{Zn}$ content for pressed oils can be explained by contamination from moving metal elements in direct contact with the oleaginous material. The presence of metals (even nontoxic) in the oil may affect in time its quality by the action of catalyzing of some oxidative degradation processes. To minimize oxidative degradation it is necessary to avoid metal contamination from pressing elements.

The IR spectra of the two oils are presented in Figure 1a, b.

The spectral bands for both types of oil are: $\vartheta_{C=o \text { esteric }}=1742.85 \mathrm{~cm}^{-1}$; $\vartheta_{\mathrm{CH}_{2}}^{\mathrm{as}}=2922.56 \mathrm{~cm}^{-1} ; \vartheta_{\mathrm{CH}_{2}}^{\mathrm{as}}=2921.54 \mathrm{~cm}^{-1}, \vartheta_{\mathrm{CH}_{2}}^{\mathrm{s}}=2853.18 \mathrm{~cm}^{-1}, \vartheta_{C-O}=1160.54$ $\mathrm{cm}^{-1} ; 1095.70 \mathrm{~cm}^{-1}$. These spectral bands illustrate the vibrations of the functional groups ( $-\mathrm{C}_{\mathrm{O}}-\mathrm{-}-\mathrm{H}=\mathrm{H}-;-\mathrm{CH}_{3} ; \mathrm{CH}_{2}$ ) from the triglyceride structure, the majority components of all oils. 


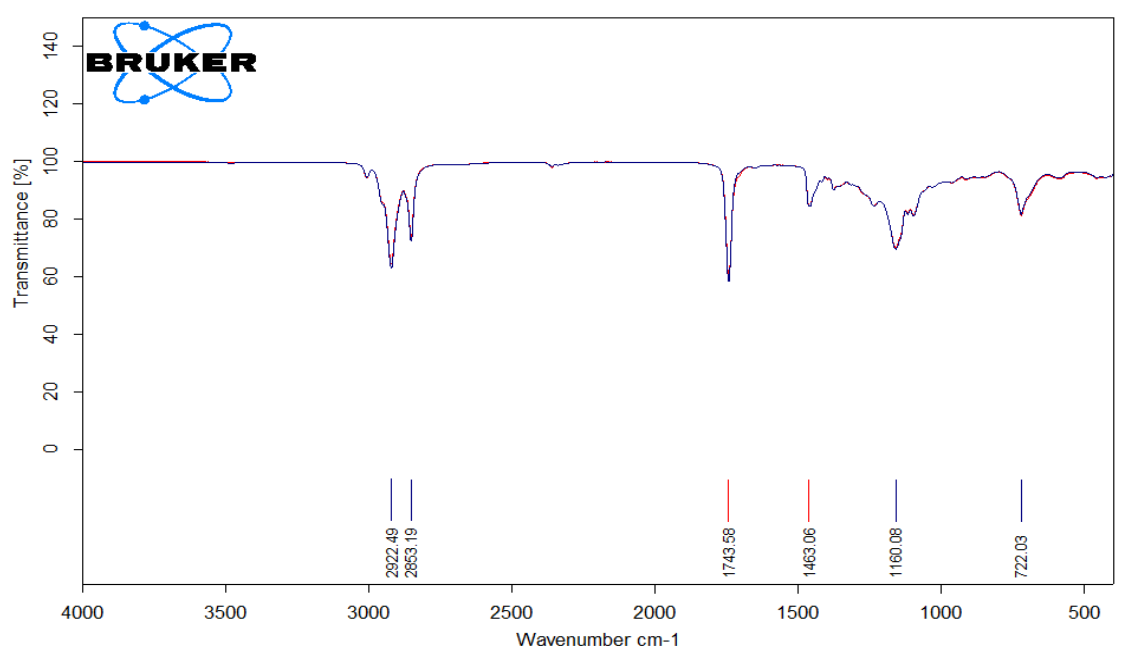

Figure 1a. The IR spectrum of walnuts oils

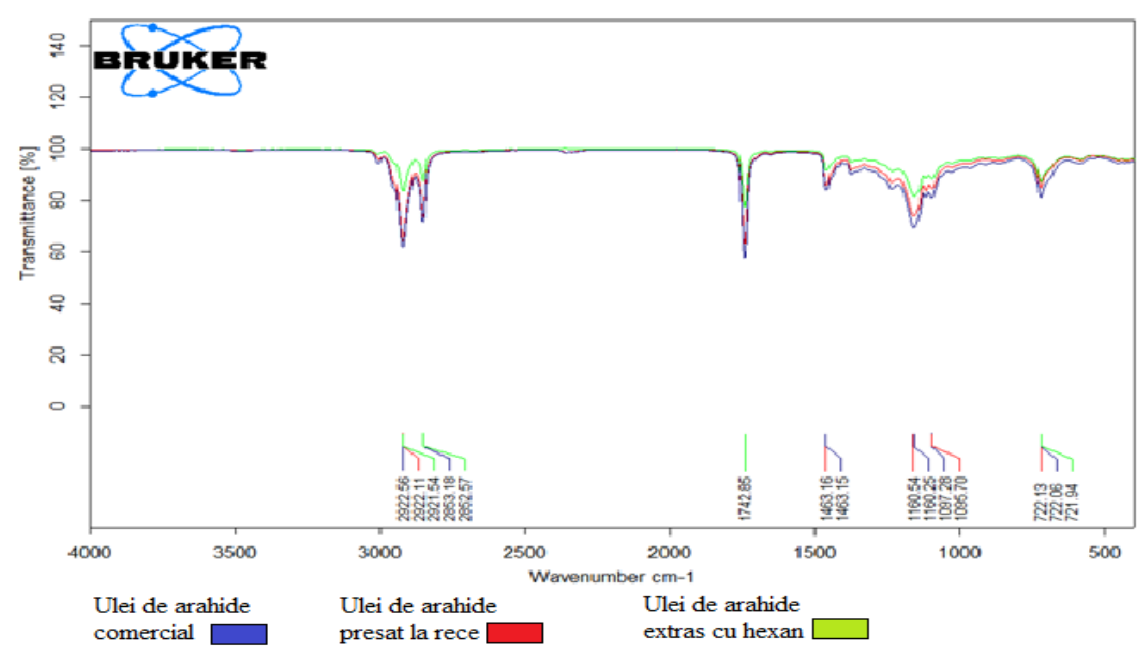

Figure 1b. The IR spectrum of peanuts oils

The IR spectra overlap perfectly regardless of the oil and the obtaining method, the distribution of fatty acids not influencing the position of the bands.

The distribution of the fatty acids in the oils is presented in Table 5. 
Table 5. The distribution of fatty acids in the oils

\begin{tabular}{|c|c|c|c|c|c|c|}
\hline & & C16:0 & C18:2 & C18:1 & C18:0 & C20:0 \\
\hline \multirow[t]{2}{*}{$\begin{array}{l}\text { Walnuts } \\
\text { oil }\end{array}$} & $\begin{array}{l}\text { Cold } \\
\text { pressing }\end{array}$ & 5.08 & 62.75 & 29.50 & 1.96 & 0.71 \\
\hline & $\begin{array}{l}\text { Soxhlet } \\
\text { extraction }\end{array}$ & 5.08 & 62.75 & 29.50 & 1.96 & 0.71 \\
\hline \multirow[t]{2}{*}{$\begin{array}{l}\text { Peanuts } \\
\text { oil }\end{array}$} & $\begin{array}{l}\text { Cold } \\
\text { pressing }\end{array}$ & 5.19 & 14.68 & 73.64 & - & - \\
\hline & $\begin{array}{l}\text { Soxhlet } \\
\text { extraction }\end{array}$ & 3.57 & 17.08 & 69.75 & - & - \\
\hline
\end{tabular}

For walnuts and peanuts oils obtained by cold pressing, the $\tau=f(\dot{\gamma})$ dependence is shown in Figure 2.

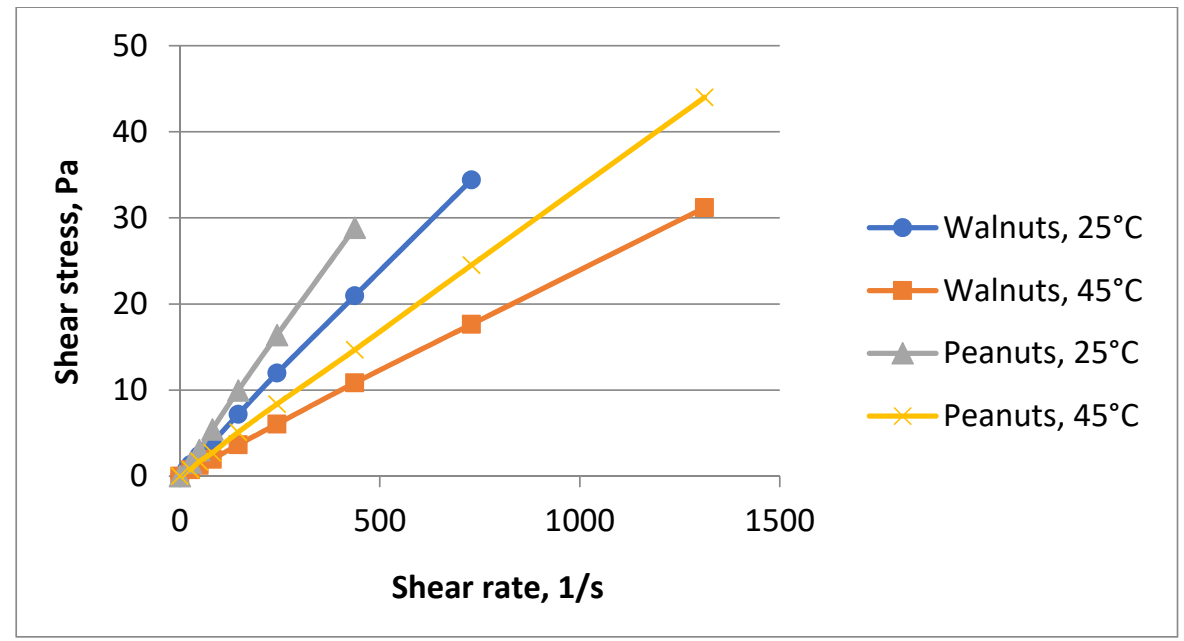

Figure 2. Shear stress $(\tau)$ vs. shear rate $(\dot{\gamma})$ for walnuts and peanuts oils at different temperature values

It is noted that for both oils the dependence $\tau=f(\dot{\gamma})$ is linear, which shows a Newtonian behaviour. Increasing temperature led to a decrease in the viscosity of the samples but without change of the Newtonian behaviour.

Using the TableCurve 2D program, the rheological equations corresponding to these dependences were established (Table 6). From the slopes of the obtained straight lines, it was observed that the peanuts oil has a higher dynamic viscosity, on average $41,5 \%$, compared to that of walnuts oil. 
The exponential decrease of the samples viscosity with temperature is described by an Arrhenius-type equation:

$$
\eta=A \cdot \exp \left(\frac{E_{a}}{R \cdot T}\right)
$$

where: $E_{a}$ - the activation energy of viscous flow, $J \cdot \mathrm{mol}^{-1} ; R$ - the universal gas constant $J \cdot \mathrm{mol}^{-1} \cdot K^{-1} ; T$ - the absolute temperature, $K ; A$ - material constant, $\mathrm{Pa} \cdot \mathrm{s}[10,11]$.

Table 6. Rheological equations for cold-pressed walnuts and peanuts oils

\begin{tabular}{|c|c|c|c|}
\hline \multirow{2}{*}{$\begin{array}{c}\text { Temperature } \\
{ }^{\circ} \mathrm{C}\end{array}$} & \multicolumn{2}{|c|}{ Eq. $\tau=\eta \cdot \dot{\gamma}$} & $\begin{array}{c}\text { Viscosity } \\
\text { increasing, } \\
\%\end{array}$ \\
\cline { 2 - 3 } & Walnuts oil & Peanuts oil & 39.5 \\
\hline 25 & $\tau=0.0476 \cdot \dot{\gamma}$ & $\tau=0.0664 \cdot \dot{\gamma}$ & 44.5 \\
\hline 35 & $\tau=0.033 \cdot \dot{\gamma}$ & $\tau=0.0477 \cdot \dot{\gamma}$ & 40.4 \\
\hline 45 & $\tau=0.024 \cdot \dot{\gamma}$ & $\tau=0.0337 \cdot \dot{\gamma}$ & \\
\hline
\end{tabular}

*Peanuts oil compared to walnuts oil

Through the measurements at different temperatures, it was possible to establish the dependence $\ln \eta=f(1 / T)$ and to calculate the $E_{a}$ values. Particular expressions of eq.(1) for the two oils are given in Table 7.

Table 7. Arrhenius-type equations for walnuts and peanuts oils

\begin{tabular}{|c|c|c|}
\hline Oil type & Eq. $\left(\eta=A \times 10^{6} \exp \left(E_{a} / R \cdot T\right)\right)$ & $\begin{array}{c}\mathbf{E}_{\mathbf{a}}, \\
\mathrm{kJ} \cdot \mathrm{mol}^{-1}\end{array}$ \\
\hline Walnuts (cold-pressed) & $\eta=0.86 \exp (3251 / T)$ & 27.0 \\
\hline Walnuts (Soxhlet) & $\eta=2.25 \exp (2860 / T)$ & 23.8 \\
\hline Peanuts (cold-pressed) & $\eta=1.41 \exp (3207 / T)$ & 26.6 \\
\hline
\end{tabular}

\section{CONCLUSIONS}

The low humidity of walnuts and peanuts is a prerequisite for longterm storage stability under appropriate conditions and, consequently, of properly obtained oils. 
Gas chromatographic analysis of the fatty acid methyl esters revealed a higher content $(62.57 \mathrm{wt} . \%)$ of linoleic acid in walnuts than in peanuts (35.33 wt.\%) where the majority is oleic acid $(69 \div 73$ wt.\%).

Linoleic acid (Omega-6) is one of the essential fatty acids that enter the structure of cell membranes and is involved in the structure of prostaglandins. The lower linoleic acid content of peanuts oil is expected to provide better thermal stability.

By the composition and the ratio of the fatty acids contained, both oils are valuable components of a balanced diet.

Although the oil yields are slightly higher for solvent extraction compared to pressing, it must be taken into account that the first method involves an additional desolvation operation and the oil contamination with traces of solvent. Regarding pressing, the efficiency can be improved by using more efficient pressing machines.

\section{EXPERIMENTAL SECTION}

The raw materials were of Romanian origin: walnuts from Caransebeș area, and peanuts from southern Oltenia (Bratovoiești, Dolj).

The oils were obtained by two methods: cold pressing (Piteba press) and extraction in hexane by the Soxhlet method, followed by desolvation through the vacuum evaporation of hexane.

In order to obtain the oils, the moisture content of the nuts was determined by means of a MA X2 moisture analyzer.

Before the oils were obtained, the walnuts/peanuts were dried in the oven at $60^{\circ} \mathrm{C}$ for 12 hours. Cold pressing was carried out with the Piteba press after a preliminary grinding of nuts. To increase the separation efficiency, the remaining oil in the press cake was separated by vacuum filtration at $5 \mathrm{mmHg}$. In the case of extraction, a Soxhlet apparatus was used. Two samples of $100 \mathrm{~g}$ dried and crushed nuts were extracted, successively, with $400 \mathrm{~mL}$ of hexane (for each sample 6 siphons). The hexane was removed by means of a rotary evaporator at $270 \mathrm{mmHg}$ and bath temperature $60^{\circ} \mathrm{C}$ (boiling temperature $\left.40^{\circ} \mathrm{C}\right)$.

At $20^{\circ} \mathrm{C}$, the density (Method no. 920.213) and the refractive index (Method no.921.08) were determined following AOAC methods [12].

The acidity of the oils was determined by titration with $\mathrm{KOH}$ solution toward phenolphthalein (Method no. 972.28). The saponification values were determined by refluxing with an excess of $\mathrm{KOH}$ alcoholic solution and retitrating the excess of $\mathrm{KOH}$ with hydrochloric acid toward phenolphthalein (Method 920.160). The degree of unsaturation of the oils was determined as iodine value ( $\mathrm{g} \mathrm{I}_{2} / 100 \mathrm{~g}$ oil) (Method no. 993.20) [12]. 
The peroxid values were determined by titration with $0.1 \mathrm{~N}$ sodium thiosulphate solution using starch as an indicator (Method 965.33), according to [12].

To determine the content of metals the oils were calcined at $550^{\circ} \mathrm{C}$ for 5 hours to remove the organic part. The ash resulted after calcination was mineralized with $10 \mathrm{~mL}$ of concentrated $\mathrm{HCl}$ and $5 \mathrm{~mL}$ of concentrated $\mathrm{HNO}_{3}$. After the ash dissolution the sample was filtered, washed with distilled water and brought to a volume of $50 \mathrm{~mL}$ (volumetric flask).

The elemental analysis was performed by flame atomic absorption spectrometry using the Varian AAS 280 FS atomic absorption spectrometer.

The evaluation of the fatty acids profile of the oils was performed by GC/MS analysis. A Brucker SCION 436-GC system was used (Bruker Co., Billerica, MA, USA). The acquisition and processing of GC/MS data was accomplished using the MS Workstation 8 software package for SCIONTM (Bruker Co., Billerica, MA, USA). Chromatograms and mass spectra corresponding to the chromatographic peaks were recorded using the gas chromatograph system GC/MS Thermo Scientific TRACE 1310, ITQ 1100 Ion Trap MS. The column used was TG-5MS $30 \times 0.25 \mathrm{~mm} \times 0.25 \mu \mathrm{m}$, Thermo Scientific. The MS parameters were: the transfer line temperature at $310^{\circ} \mathrm{C}$, the reading range $35-700 \mathrm{~m} / \mathrm{z}$. Specifically, the methyl esters obtained through the transesterification of the oils with methanol in the presence of $\mathrm{BF}_{3}$, were used. As internal standard was used hexadecane.

The rheological characterization of the oils was carried out under thermostatic conditions (temperature range $25 \div 45^{\circ} \mathrm{C}$ ), using a rotation viscometer Rheotest-2. The device allows the measurement of the torsion moment appeared thanks to the ring-shaped substance layer placed between a fixed cylinder and a rotating one with known revolution. The torsion moment is correlated with the shear stress $(\tau)$. The revolution and the ring-shaped layer thickness determine the shear rate $(\dot{\gamma})$. The flow curves $\tau=f(\dot{\gamma})$ of the oil samples were plotted by increasing (forward measurements) and decreasing (backward measurements) the shear rate in the range $3 \div 1312 \mathrm{~s}^{-1}$. Average shear stresses were calculated.

\section{REFERENCES}

1. C. Hudthagosol; E. Haddad; R. Jongsuwat; J. Med. Assoc. Thai, 2012, 95(6), S179-S188

2. H. Jamshed; F.A. Sultan; R. Iqbal; A.H. Gilani; J. Nutr., 2015, 145(10), 2287-2292

3. L.Wu; K. Piotrowski; T. Rau; E. Waldmann; U.C.Broedl; H. Demmelmair et al., Metabolism, 2014, 63(3), 382-391 
4. P. Lopez-Uriarte; R. Nogues; G. Saez; M. Bullo; M. Romeu; L. Masana; C. Tormos; P. Casas-Agustench; J. Salas-Salvado, Clin.Nutr., 2010, 29(3), 373-380

5. G. Grosso; R. Estruch, Maturitas, 2016, 84, 11-16

6. R. Saxena; D.D. Joshi; R. Singh, Int. J. Essent. Oil Ther., 2009, 3, 1-4

7. https://www.organicfacts.net/health-benefits/oils/peanut-oil.html, accessed on 16.03.2019

8. www.afir.ro, accessed on 27.10 .2018

9. Juranovic, M. Zeiner, D. Hlebec, Int. J. Environ. Res. Public Health, 2018, 15, 2674-2682

10.T. Budtova; P. Navard, Nord. Pulp \& Pap.Res.J., 2015, 30(1), 99-104

11.S. Goh; E. Giap, Int. J. Phys. Sci., 2010, 21(1), 29-39

12. Official Methods of Analysis of AOAC International, edited by P. Cunniff, $16^{\text {th }}$ ed., AOAC International, Arlington, 1995, Methods 920.213, 921.08, 972.28, 920.160, 993.20, 965.33. 